\title{
Analisis Kesulitan Belajar Siswa Materi Bioteknologi SMA Negeri Se- Kabupaten Rokan Hilir
}

\author{
Zulpadly $^{1^{*}}$, Fauziyah Harahap ${ }^{2}$, Syahmi Edi $^{2}$ \\ ${ }^{1}$ Guru Biologi di SMA Negeri 3 Bangko Pusako Jln. Lintas Riau Sumut K.m. 3 Rokan hilir, Riau. \\ ${ }^{2}$ Program Studi Pendidikan Biologi Pascasarjana Universitas Negeri Medan, Sumatera Utara, Indonesia \\ *E-mail: zulpady 79 @ gmail.com
}

\begin{abstract}
This study aims to determine students' learning difficulties in analyzing the material Biotechnology in view of the indicator. This research is descriptive quantitative study population of SMA as Rokan downstream terdir from SMAN 11 with a sample of as many as 644 people overall. The sampling technique used random sampling techniques. The data collection technique is a multiple-choice test instrument, for trouble indicator boteknologi materials, the data is processed by using a percentage. Judging from the indicators difficulties, learning difficulties on indicators derived their understanding of basic principles of biotechnology and $49.90 \%$, explain the science related to biotechnology $46.44 \%$, explaining the differences of traditional and modern biotechnology $52.23 \%$, $67,44 \%$ Explaining the process of genetic engineering \%, explaining $63.44 \%$ tissue culture process, explain the process of gene recombinant $63.07 \%, 48,60 \%$ describes an example of genetic engineering, explained the impact of the use of biotechnology $48.06 \%$, describes the impact of using genetically engineered $63,17 \%$.
\end{abstract}

Keywords: Difficulty, Biotechnology, Engineering, Genetic Indicators

\begin{abstract}
Abstrak: Penelitian ini bertujuan untuk mengetahui menganalisis kesulitan belajar siswa pada materi Bioteknologi di lihat dari indikator. Penelitian ini bersifat deskriptif kuantitatif, populasi dari penelitian SMA Negerise- Kabupaten Rokan hilir yang terdir dari 11SMAN dengan jumlah sampel keseluruhan sebanyak 644 orang. Teknik pengambilan sampel digunakan teknik random sampling. Teknik pengumpulan data adalah instrument tes pilihan berganda, untuk kesulitan indikator materi boteknologi,data diolah dengan teknik persentase. Ditinjau dari Indikator kesulitan , diperoleh kesulitan belajar pada indikator menjelaskan pengertian bioteknologi dan prinsip dasar 49,90\%,menjelaskan ilmu yang berkaitan dengan bioteknologi 46,44\%,menjelaskan perbedaan bioteknologi tradisional dan modern 52,23\%,Menjelaskan proses rekayasa genetika 67,44\%, menjelaskan proses kultur jaringan 63,44\%, menjelaskan proses rekombinan gen $63,07 \%$, menjelaskan contoh rekayasa genetika 48,60, menjelaskan dampak penggunaan bioteknologi 48,06, menjelaskan dampak penggunaan rekayasa genetika $63,17 \%$.
\end{abstract}

Kata Kunci: Kesulitan, Bioteknologi,Rekayasa, genetika Indikator

\section{PENDAHULUAN}

Bioteknologi merupakan cabang ilmu yang mempelajari pemanfaatan prinsipprinsip ilmiah yang menggunakan makhluk hidup untuk menghasilkan produk dan jasa untuk kepentingan manusia (Putra, 2013). Polingkinghone

dalam (Todd\&Murphy,2003) menyatakan bahwa" bioteknologi merupakan salah satu disiplin ilmu yang relatife sulit tetapi merupakan ilmu yang berkembang sangat kompleks dan minimbulkan banyak perdebatan diberbagai area seperti etika politik dan moral". Menurut Purwaningsih (2009) bahwa"Bioteknologi dikenal sebagai ilmu yang bersipat multi disipliner dan aplikatif sehingga membutuhkan penguasaan konsep dasar yang cukup dan perkembangannya sangat pesat karena bioteknologi bersentuhan dengan peningkatan taraf hidup manusia".

Penggunaan Bioteknologi sebagai ilmu maupun sebagai alat yang bertanggung jawab dalam meningkatkan kemajuan secara cepat dalam berbagai bidang kehidupan. Pesatnya perkembangan ilmu dan teknologi menjadikan Bioteknologi salah satu bidang ilmu yang harus dikuasai bangsa Indonesia,, termasuk para siswa SMA. Hal tersebut dikarenakan, selain 
banyak terkait langsung dengan kehidupan sehari-hari, juga dapat dikaitkan dengan aspek"life skill". Untuk memberikan penguasaan dan kebermaknaan yang baik terhadap pembelajaran bioteknologi, diharapkan kepada siswa mampu melakukan pembelajaran bioteknologi yang benar dan sesuai dengan pemahaman yang baik.Menurut Hagerdon (dalam Sohan et al, 2003) siswa-siswa sekolah saat ini perlu memiliki pemahaman yang baik terhadap resiko dan keuntungan dari Bioteknologi untuk dapat memutuskan secara cerdas penggunaan pengetahuan tersebut secara benar.

Beberapa penelitian menunjukkan adanya hubungan positif antara peningkatan penguasaan dan sikap siswa serta persepsi positip terhadap Bioteknologi (Souhan,2003; Dawson \& Schibei,2003: Bal, et al,.2007). Dengan demikian dapat dikatakan bahwa apabila seorang siswa telah menguasai dengan benar dan mampu memutuskan secara kritis tentang bioteknologi, maka mereka akan dapat bersikap secara benar terhadap bioteknologi. Oleh karenanya kesulitan memahami konsep Bioteknologi haruslah menjadi bagian dari unsur yang di bekalkan kepada siswa. Dawson \& Shicebeci (2003) menyatakan bahwa dari jumlah siswa yang diteliti di Australia, sepertiganya mempunyai pemahaman yang rendah atau tidak memahami sama sekali tentang Bioteknologi dan sepertiganya lagi tidak dapat memberikan satu contohpun tentang hasil Bioteknologi secara benar. Penguasaan yang rendah dari siswa maupun masyarakat umum terhadap ilmu tersebut, sangat mungkin disebabkan karena kesulitan siswa dalam pembelajaran bioteknologi di sekolah, sehingga di perlukan penyiapan yang matang dalam pembelajaran di bidang ini.

Terkait dengan hasil belajar bioteknologi yang rendah atau penyebab rendahnya KKM pada materi biotekhnologi diduga banyak faktor penyebabnya,seperti faktor dari dalam diri siswa itu sendiri dan faktor lainnya. Dalam pembelajaran biologi materi bioteknologi konvensional seperti pembuatan tempe dan tahu siswa masih mengalami kesulitan jika harus praktek langsung di lapangan, yang sering terjadi pembelajaran dilakukan dengan ceramah atau penyampaian konsep.Padahal dalam pembelajaran bioteknologi tidak hanya konsep tetapi juga aplikasi (Purwaningsih, 2009), kesulitan berikutnya adalah kekurangan alat untuk mengamati terjadinya proses bioteknologi. Proses Bioteknologi memerlukan waktu beberapa hari, sehingga untuk melakukan pengamatan secara langsung dalam percobaan tidak dapat diperoleh hasilnya dalam waktu 5 jam pelajaran.

Guru sebagai faktor eksternal sangat menentukan keberhasilan belajar siswa. Penelitian terakhir menujukkan bahwa guru sains mengenali adanya kebutuhan untuk mengajarkan bioteknologi, tetapi masih sedikit yang terlaksana. Faktor - faktor yang membatasi pengajaran bioteknologi meliputi: kurangnya keahlian guru dalam konten bidang ini, kurangnya pengalaman dalam kecocokan aktivitas mengajar, kurangnya sumber dan materi kurikulum dan kurangnya watu mengajar (Dawson \& Scbei,2003).

Peran siswa didaerah pinggiran ketika dirumah merangkap sebagai tenaga produktif untuk membantu laju ekonomi keluarga, siswa merupakan asset keluarga yang harus berperan aktif dalam aktivitas perekonomian keluarga. siswa menjadi sumber daya pendukung bagi kelancaran aktivitas mata pencaharian orangtua. Kondisi seperti ini mempengaruhi phisik disaat mengikuti pembelajaran bioteknologi disekolah, rendahnya minat dan motivasi belajar siswa di tandai dengan rendahnya presentasi siswa yang mengerjakan tugastugas yang di berikan guru seperti praktikum dan pekerjaan rumah sehingga tidak mencapai KKM 76.Dawson \& Shicebeci (2003) menyatakan bahwa : dari jumlah siswa yang diteliti di Australia, sepertiganya mempunyai pemahaman yang rendah atau tidak menunjukkan adanya hubungan positif antara peningkatan penguasaan dan sikap siswa serta persepsi positip terhadap bioteknologi (Souhan,2003; Dawson \& Schibei,2003: Bal, et al,.2007). 
Dengan demikian dapat dikatakan bahwa apabila seorang siswa telah menguasai dengan benar dan mampu memutuskan secara kritis tentang bioteknologi, maka mereka dapat bersikap secara benar terhadap bioteknologi. Oleh karenanya kesulitan memahami konsep bioteknologi haruslah menjadi bagian dari unsur yang di bekalkan kepada siswamemahami sama tidak memahami sekali tentang bioteknolog secara benar. Penguasaan yang rendah dari siswa maupun masyarakat umum terhadap ilmu tersebut, sangat mungkin disebabkan karena kesulitan siswa dalam pembelajaran bioteknologi di sekolah, sehingga di perlukan penyiapan yang matang dalam pembelajaran di bidang ini.

Beberapa penelitian menunjukkan adanya hubungan positif antara peningkatan penguasaan dan sikap siswa serta persepsi positip terhadap Bioteknologi (Souhan,2003; Dawson \& Schibei,2003: Bal, et al,.2007). Dengan demikian dapat dikatakan bahwa apabila seorang siswa telah menguasai dengan benar dan mampu memutuskan secara kritis tentang bioteknologi, maka mereka akan dapat bersikap secara benar terhadap bioteknologi. Oleh karenanya kesulitan memahami konsep bioteknologi haruslah menjadi bagian dari unsur yang di bekalkan kepada siswa. Dawson \& Shicebeci (2003) menyatakan bahwa dari jumlah siswa yang diteliti di Australia, sepertiganya mempunyai pemahaman yang rendah atau tidak memahami sama sekali tentang bioteknologi dan sepertiganya lagi tidak dapat memberikan satu contoh pun tentang hasil bioteknologi secara benar. Penguasaan yang rendah dari siswa maupun masyarakat umum terhadap ilmu tersebut, sangat mungkin disebabkan karena kesulitan siswa dalam pembelajaran bioteknologi di sekolah, sehingga di perlukan penyiapan yang matang dalam pembelajaran di bidang ini.

Berdasarkan hasil observasi di beberapa SMA Negeri di Kabupaten Rokan hilir, didapatkan keterangan bahwa perolehan nilai rata- rata peserta didik masih banyak yang belum mencapai KKM, berdasarkan Standar Nasional Pendidikan (BSNP) yaitu 76. Di Kabupaten Rokan hilir contohnya, nilai rata- rata perolehan siswa pada materi bioteknologi baru mencapai nilai 70, di SMAN 2 Pujud mencapai nilai 70, SMAN 1 Bangko mencapai nilai 70, sedangkan rata- rata di SMAN 2 Bagan Sinembah mencapai nilai 68. Tidak tercapainya nilai siswa sesuai KKM dapat dijadikan sebagai indikator bahwa telah terjadi kesulitan belajar siswa pada materi bioteknologi. Kesulitan belajar siswa pada umumnya pada indikator materi bioteknologi modern yang bersipat abstarak dan mengakaji sesuatu yang bersipat molekuler.

Untuk mengatasi kesulitan siswa pada materi bioteknologi, maka perlu dilakukan penelitian untuk menganalisis faktor penyebab kesulitan belajar tersebut. Berdasarkan permasalahan- permasalah yang telah dikemukakan diatas maka perlu diambil langkah - langkah strategis dan nyata untuk melakukan inovasi pembelajaran bioteknologi sesuai dengan permasahan yang dihadapi siswa

\section{METODE PENELITIAN \\ Lokasi dan Waktu Penelitian}

Penelitian telah dilakukan dikelas XII IPA SMA Negeri Se-Kabupaten Rokan hilir penelitian telah dilakukan pada bulan Maret - Mei 2016.

\section{Populasi dan Sampel .}

Populasi dalam penelitian ini adalah seluruh siswa - siswi kelas XII di 32 SMAN Negeri se- Kabupaten Rokan hilir yang tersebar di 13 kecamatan dan berjumlah 1920 orang. Dari jumlah tersebut peneliti kemudian menetapkan sampel sebanyak 644 siswa yang dari populasi tersebut yang berada pada 11 sekolah dengan lokasi yang berbeda, penetapan jumlah sampel berdasarkan kemampuan peneliti berdasarkan pertimbangan waktu. Pengambilan sampel data menggunakan non random sampling Dalam penelitian ini, teknik sampel yang digunakan non random sampling yaitu ada pada 11 SMA Negeri yang mewakili sampel total yang berjumlah 1920 orang dari 32 SMA Negeri di 
Kabupaten Rokan hilir yang terdapat di Kota dan pinggiran. .

\section{HASIL PENELITIAN}

Hasil tes penguasaan materi Bioteknologi dari 644 orang diperoleh data nilai rata-rata hasil belajar siswa sebesar $=44,25$ dengan simpangan baku = 7,52 dengan rata-rata persentase ketuntasan belajar siswa seluruhnya sebesar 10,87\%. Kemudian persentase ketuntasan belajar siswa dari hasil penguasaan materi bioteknologi dapat dilihat dari tabel dibawah ini :

Tabel 1. Jumlah yang Tuntas dan Tidak Tuntas dalam Tes Penguasaan Materi Bioteknologi Di SMA Negeri Se- Kabupaten Rokan Hilir Berdasarkan KKM 75 (\%).

\begin{tabular}{lcccc}
\hline \multirow{2}{*}{ Sekolah } & \multicolumn{3}{c}{ Hasil Penguasaan materi Bioteknologi } \\
\cline { 2 - 5 } & \multicolumn{2}{c}{ Tidak tuntas } & \multicolumn{2}{c}{ Tuntas } \\
\cline { 2 - 5 } & Jumlah & $\%$ & Jumlah & $\%$ \\
\hline SMAN 2 Pujud & 48 Orang & 87,27 & 7 Orang & 12,73 \\
SMAN 5 Tanah Putih & 26 Orang & 86,67 & 4 Orang & 13,33 \\
SMAN 4 Tanah Putih & 20 Orang & 86,96 & 3 Orang & 13,04 \\
SMAN 1 Kubu & 90 Orang & 93,75 & 6 Orang & 6,25 \\
SMA 2 Bangko Pusako & 75 Orang & 90,36 & 8 Orang & 9,64 \\
SMAN 2 B.Sinembah & 62 Orang & 86,11 & 10 Orang & 13,89 \\
SMA N 1 R.Melintang & 49 Orang & 89,09 & 6 Orang & 10,91 \\
SMAN 1 T. Melawan & 43 Orang & 86,00 & 7 Orang & 14,00 \\
SMAN 4 B.Pusako & 63 Orang & 91,30 & 6 Orang & 8,70 \\
SMAN 1 Bangko & 51 Orang & 87,93 & 7 Orang & 12,07 \\
SMAN 1 B.Hampar & 47 Orang & 88,68 & 6 Orang & 11,32 \\
\hline \multicolumn{1}{c}{ Jumlah } & 574 Orang & 89,13 & 70 Orang & 10,87 \\
\hline
\end{tabular}

Dari 644 orang siswa yang di lakukan tes diagnostik sebanyak $574 \quad(89,13 \%)$ siswa tidak tuntas pada materi bioteknologi, yaitu sebanyak $48(87,27 \%)$ siswa dari SMAN 2 Pujud, $26(86,67, \%)$ siswa dari SMAN 5 Tanah Putih, 20 (86,96\% siswa SMAN 4 Tanah Putih, 90 $(86,96 \%)$ siswa SMAN 1 Kubu, 75 $(93,75 \%)$ siswa SMA 2 Bangko Pusako, 62 $(86,11)$ siswa SMAN 2 B Sinembah,49 $(89,09)$ siswa SMAN 1 Rimba Melintang, $43(86,00 \%)$ siswa SMAN 1 Tanjung
Melawan, $63(91,30 \%)$ siswa SMAN 4 Bangko Pusako, $51(87,93 \%)$ siswa SMAN 1 Bangko, 47 (88,68\%) SMAN 1 Batu Hampar.

Dari 9 Indikator yang ada diperoleh rata-rata kesulitan belajar siswa setiap indikator dapat disajikan dalam bentuk diagram gambar. Sebaran rata - rata persentase kesulitan belajar siswa setiap indikator pada materi Bioteknologi SMA Negeri se- Kabupaten Rokan hilir di sajikan pada Gambar 1. 


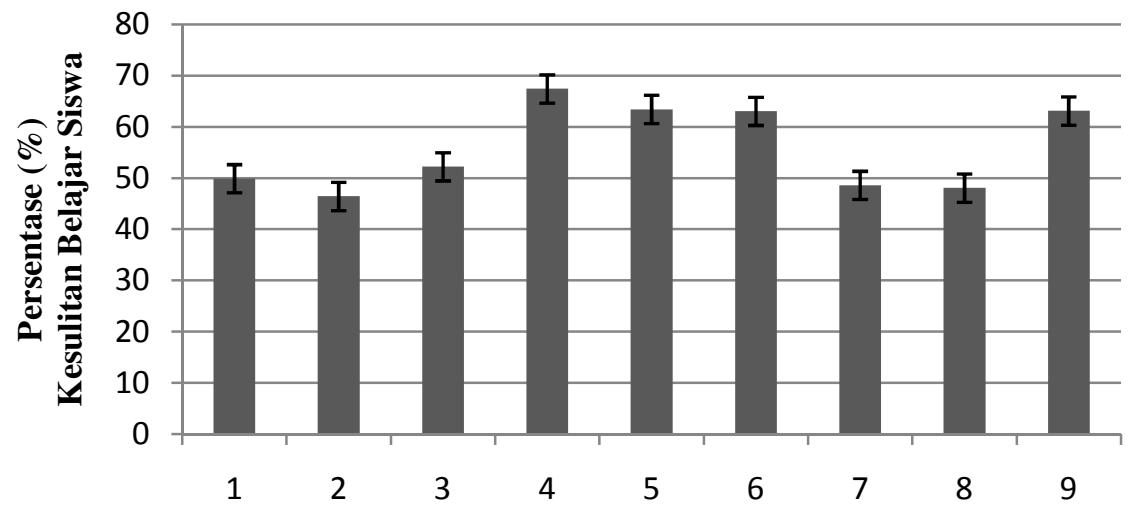

Keterangan :

$1=$ Menjelaskan arti dan prinsip dasar Bioteknologi

2 = Menjelaskan ilmu yang berkaitan dengan Bioteknologi

$3=$ Menjelaskan perbedaan bioteknologi tradisional dan modern

$4=$ Menjelaskan contoh proses rekayasa genetika

$5=$ Menjelaskan proses kultur jaringan

$6=$ Menjelaskan proses rekombinan gen

$7=$ Memberikan contoh produk rekayasa genetika

$8=$ Menjelaskan dampak penggunaan bioteknologi

$9=$ Menjelaskan dampak penggunaan rekayasa genetika

Gambar 1. Rata-rata (\%) kesulitan belajar siswa setiap indikator pada Materi Bioteknologi di SMA Negeri Se-Kabupaten Rokan Hilir.

\section{PEMBAHASAN}

\section{Analisis Kesulitan Belajar Siswa pada Indikator Materi Bioteknologi}

Berdasarkan hasil penelitian dengan menggunakan pilihan ganda untuk mengetahui penguasaan materi bioteknologi menunjukkan bahwa siswa mengalami kesulitan dalam mempelajari materi bioteknologi. Hal ini terlihat banyaknya siswa yang tidak tuntas untuk setiap indikator materi yang di ajarkan. Hal sesuai dengan pendapat yang disampaikan Ariani (2003), Bioteknologi bersipat aflikatif dan abstrak sehingga bioteknologi modern membutuhkan penguasaan dan konsep dasar yang benar. Dari banyaknya siswa yang diperolah dari siswa yang tidak tuntas 574 siswa atau sebesar 89,13\% dan dan siswa yang tuntas sebanyak 70 siswa atau sebesar $10,87 \%$. Untuk tingkat kesulitan berada pada kategori sedang dan tinggi, ini sesuai dengan hasil tes dan wawancara yang dilakukan terhadap siswa yang mengatakan bahwa siswa mengalami kesulitan mempelajari materi bioteknologi.

Berdasarkan ketegori yang digunakan rentang skor yang diperoleh termasuk ketegori tinggi. Tingkat kesulitan belajar siswa pada kategori tinggi terdapat pada indikator menjelaskan proses rekayasa genetika sebesar $67,44 \%$, menjelaskan proses kultur jaringan sebesar 63,44\%, menjelaskan proses rekombinasi gen sebesar 63,07\% dan menjelaskan dampak penggunaan rekayasa genetika sebesar 63,17. Sedangkan Tingkat kesulitan belajar siswa yang tergolong pada kategori sedang terdapat pada indikator menjelaskan pengertian bioteknologi dan prinsip dasar sebesar 49,90\%, menjelasakan ilmu yang berkaitan dengan bioteknologi sebesar $46,44 \%$, menjelasakan perbedaan bioteknologi tradisional dan modern sebesar 52,23\%, menjelaskan contoh produk rekayasa genetika sebesar 48,60\% dan menjelaskan dampak penggunaan bioteknologi sebesar 48,06\%.

Dari kesembilan indikator materi bioteknologi tingkat kesulitan yang tinggi yaitu menjelaskan proses rekayasa genetika dengan persentase sebesar $67,44 \%$. Tingginya tingkat kesulitan pada materi ini disebabkan siswa tidak pernah melakukan proses rekayasa genetika secara langsung.

Selanjutnya materi yang mengalami kesulitan tinggi adalah indikator kelima yaitu Menjelaskan proses kultur jaringan persentase sebesar $63,44 \%$ dengan indikator 
mengurutkan langkah-langkah dalam pembentukan kultur jaringan dan dan indikator kedua mengidentifikasi proses dan keuntungan serta melakukan kultur jaringan. Materi ini dsebabkan siswa tidak memahami proses dan lengkah- langkah dalam melakukan kultur jaringan, siswa juga kurang memahami keuntungan dan kerugian kultur jaringan.

Materi yang mengalami kesulitan tinggi ketiga yaitu pada indikator menjelaskan dampak penggunaan rekayasan genetika dengan persentase sebesar $63,17 \%$ dengan kategori tinggi. Hal ini disebabkan materi dampak penggunaan rekayasa genetika adalah hal yang baru dan pada materi ini lebih banyak memahami proses individu dengan proses rekayasa genetika.

Materi yang mengalami kesulitan tinggi keempat yaitu pada indikator menjelaskan proses rekombinasi gen dengan persentase sebesar $63,07 \%$ dengan kategori tinggi dengan indikator mengidenifikasi proses dan produk rekombinasi gen dengan tingkat baru yang kita inginkan. Hal ini disebabkan materi rekombinasi gen hal yang baru dan pada materi ini lebih banyak memahami proses individu dengan teknologi gen, siswa sulit untuk mengingat dan memahami proses rekombinasi dan yang di pakai dalam rekombinasi gen.

Besarnya tingkat kesulitan yang dialami siswa untuk materi bioteknologi disebabkan sebagian besar bersifat abstrak. Sebagai contoh siswa mengalami kesulitan membayangkan proses jaringan kloning pada hewan. Sekain itu besarnya kesulitan yang dialami siswa pada pada materi bioteknologi terutama pada materi rekombinan gen dan dampak bioteknologi modern maupun kultur jaringan disebabkan miskinnya pemahaman konsep pada siswa. Sudarman (2005), menyatakan bahwa salah satu masalah yang dihadapi dunia pendidikan adalah masalah lemahnya proses pembelajaran. Proses pembelajaran di kelas masih diarahkan pada kemampuan anak untuk mengingat informasi. Pendidkan di sekolah saat ini terlalu menuntut anak harus menghapal berbagai bahan ajar yang harus diingat.

Pembelajaran bioteknologi adalah kegiatan pembelajaran aflikasi dari organisme biologis sistem dan proses rekayasa dalam industry barang dan jasa untuk kepentingan manusia (Hartono, 2011), sehingga di perlukan metode pembelajaran yang tepat sehingga mudah dipahami. Peran guru dan metode pembelajaran faktor motivasi siswa harus maksimal agar siswa memperoleh hasil yang diharapkan. Ausabel dalam Dahar (2008), menekankan agar para guru mengetahui konsep - konsep yang relevan yang telah ada dalam struktur kognitif (otak) siswa, bila dalam struktur kognitif tidak terdapat konsep- konsep yang relevan maka pengetahuan baru yang di pelajari hanyalah hapalan semata.

\section{KESIMPULAN}

Kesulitan belajar siswa berdasarkan indikator yang tinggi adalah pada indikator menjelaskan proses rekayasa genetika, menjelaskan proses kultur jaringan, menjelaskan proses rekombinasi gen dan menjelaskan dampak penggunaan rekayasa genetika dengan kategori tinggi.

\section{DAFTAR PUSTAKA}

Ariani, S. 2003. Peranan Thricoderma harzianum terhadap Kecepatan Dekomposisi Berbagai Sumber Bahan Organic dan Kualitas Kompos yang Dihasilkannya. Padang: Skripsi Sarjana Pertanian Universitas Andalas.

Dawson, V. \& Scbeci, R, 2003.Westeren Austaralia High School Student Attitudes toward Biotecnology Process. Journal of Biological. 38(1):60-67.

Dahar, R, 2006. Teori dan Pembelajaran. Jakarta: Rineka Cipta.

Hartono, R. 2011. Bioteknologi Pengembangan Tanaman Resisten terhada Hamadan penyakit, (On line), (htt://cs.upi.edu/upload, diakses 14 Juli 2016).

Putra, S.R. 2013. Desain Evaluasi Belajar Berbasis Kinerja. Yogyakarta:DIVA Press.

Purwaningsih,W. 2009. Identifikasi Kesulitan Pembelajaran Bioteknologi padaGuru. Sekolah Pasca Sarjana Universitas Pendidikan Indonesia. Bandung. 
Jurnal Pendidikan Biologi, Vol. 6, No. 1, Edisi Desember 2016

Sudarman, 2005. Problem Based Learning Suatu Model Pembelajaran Untuk Mengembangkandan Meningkatkan Kemampuan Memecahkan Masalah.

Artikel Ilmiah FKIP Universitas Mulawarman Samarinda.
Todd, A. Morpy,D.J. 2003. “ Evaluation University Masterclsses and School visit as Mechanisms for Enhacing Teaching and Learning Experinces for Undergradute and School Pupil. A pilot Study Biotechnology Student ".Bioscince Education e journal.110 